\title{
African potato (Hypoxis hemerocallidea): a systematic review of its chemistry, pharmacology and ethno medicinal properties
}

\author{
Celia M. J. Matyanga ${ }^{1,2^{*}}$ (D), Gene D. Morse ${ }^{3}$, Mazuru Gundidza ${ }^{4}$ and Charles F. B. Nhachi ${ }^{1}$
}

\begin{abstract}
Background: African Potato (hypoxis hemerocallidea), is used for enhancing immune system in Southern Africa. It is among the plants of intense commercial and scientific interest; hence, the aim of this study was to describe its chemistry and pharmacology.

Methods: PubMed, Cochrane Controlled Trials Register (CENTRAL) and Google Scholar were searched independently for relevant literature. The last search occurred in October 2018. Other research material was obtained from Google. The following search terms were used, but not limited to: "African Potato", "hypoxis", "hemerocallidea", "rooperol." Articles that were explaining the chemistry and pharmacology of hypoxis hemerocallidea were included.

Results: Thirty articles from PubMed, Cochrane and Google Scholar were eligible. Three webpages were included from Google. Results showed that the tuberous rootstock (corm) of African Potato is used traditionally to treat wasting diseases, testicular tumours, insanity, barrenness, impotency, bad dreams, intestinal parasites, urinary infection, cardiac disease and enhancing immunity. The plant contains hypoxoside, which is converted rapidly to a potent antioxidant, rooperol in the gut. The corm contains sterols, sterol glycosides, stanols, terpenoids, saponins, cardiac glycosides, tannins and reducing sugars. A dose of $15 \mathrm{mg} / \mathrm{kg} /$ day of hypoxoside is reportedly therapeutic. Preclinical studies of African Potato have shown immunomodulation, antioxidant, antinociceptive, hypoglycaemic, anti-inflammatory, anticonvulsant, antibacterial, uterolytic, antimotility, spasmolytic and anticholinergic effects. The common side effects of African Potato are nausea and vomiting, which subside over time. In vitro, African Potato demonstrated inhibitory effects on CYP1A2, 2C9, 2D6, 3A4, 3A5, CYP19-metabolism and induction of P-glycoprotein. In vivo, it did not alter the pharmacokinetics of efavirenz or lopinavir/ritonavir.

(Continued on next page)
\end{abstract}

\footnotetext{
* Correspondence: celiammj@yahoo.com

'Department of Clinical Pharmacology, College of Health Sciences, University of Zimbabwe, Harare, Zimbabwe

${ }^{2}$ School of Pharmacy, College of Health Sciences, University of Zimbabwe, Harare, Zimbabwe

Full list of author information is available at the end of the article
}

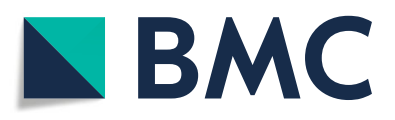

(c) The Author(s). 2020 Open Access This article is licensed under a Creative Commons Attribution 4.0 International License, which permits use, sharing, adaptation, distribution and reproduction in any medium or format, as long as you give appropriate credit to the original author(s) and the source, provide a link to the Creative Commons licence, and indicate if changes were made. The images or other third party material in this article are included in the article's Creative Commons licence, unless indicated otherwise in a credit line to the material. If material is not included in the article's Creative Commons licence and your intended use is not permitted by statutory regulation or exceeds the permitted use, you will need to obtain permission directly from the copyright holder. To view a copy of this licence, visit http://creativecommons.org/licenses/by/4.0/ The Creative Commons Public Domain Dedication waiver (http://creativecommons.org/publicdomain/zero/1.0/) applies to the data made available in this article, unless otherwise stated in a credit line to the data. 
(Continued from previous page)

Conclusion: African Potato is mainly used as an immunostimulant. The exact mechanisms of action for all the pharmacological actions are unknown. More research is required to substantiate claims regarding beneficial effects. There are many research gaps that require investigation including pharmacokinetic interactions with conventional drugs, especially those used in HIV/AIDS.

Keywords: African potato, Hypoxis hemerocallidea, Pharmacology, Pharmacokinetics, Chemistry, Traditional medicine

\section{Background}

Medicines from natural sources have increased in popularity over orthodox medicines. Natural plants offer vast chemical diversity, which produce physiological changes in the human body [1]. In 2016, the worldwide annual market for herbal medicines was valued just above US\$ 71 billion, and global health debates are focusing on traditional medicines [2]. Traditional medicines were used in historical eras and in populations in Africa, Asia, and Latin America and continue to be used due to cultural beliefs [3]. In the year 2002, severe acute respiratory syndrome (SARS) became a global disease outbreak, first appearing in China [4]. Many emergency measures were taken but there was no effective treatment [5]. The World Health Organization (WHO) reported that traditional medicine played a prominent role in the strategy to eradicate SARS in China. By late July 2003, no new cases were being reported [4].

Eighty percent of Africans use some form of traditional medicine [3] and the highest prevalence is among people living with HIV/ AIDS (PLWHA) [6, 7]. African Potato is one of the medicinal plants used for the management of human immunodeficiency virus (HIV) symptoms in Southern Africa. Its use in Africa is widespread and it is among the medicinal plants of intense commercial and scientific interest $[8,9]$.

African Potato, scientifically known as hypoxis hemerocallidea syn. Hypoxis rooperi belongs to the Hypoxidaceae family. Other common names include star lily, magic muthi or yellow stars [9]. The plant grows in the wild and is most prevalent in Southern Africa (mainly South Africa, Lesotho, Mozambique, and Zimbabwe). It is also found further into East Africa. The African Potato plant is easily identified by its star-shaped bright yellow flowers and green strap-like leaves. The tuberous rootstock (corm) is traditionally used to treat a wide variety of ailments. Extracts of the corm are used to make decoctions, which are taken as tonics against wasting diseases, tuberculosis, testicular tumors, other cancers, and HIV/ acquired immunodeficiency syndrome (AIDS) [10]. Traditionally, African Potato was used for insanity, barrenness, bad dreams, intestinal parasites, urinary infection and cardiac diseases among other diseases [11]. Nowadays it is used to increase immune function, for headache, dizziness, prostate hypertrophy, burns, and ulcers [10].

Albrecht, who thoroughly researched on African Potato, administered a methanolic extract of $H$. hemerocallidea to patients with HIV over 2 years in the mid-1990s. He reported that the CD4+ lymphocyte counts in these patients remained stable, while the serum p24 HIV antigen decreased and there was a decrease in expression of the HLA-DR CD8+ lymphocyte activation marker [12]. The HLA-DR CD8+ is used for identification of $\mathrm{T}$ lymphocytes and elevated levels are observed in HIV infection [13]. Albrecht concluded: "these studies have demonstrated that rooperol has potent, diverse and important pharmacological properties relevant to cancer, inflammation and HIV" [12].

The aim of this paper is to describe the chemistry, pharmacology and clinical properties of African Potato. Other objectives include identifying research areas for further study of the plant due to its widespread scientific interest. Reviewing the studies conducted on African Potato will reveal areas of further research.

\section{Methods}

This systematic review adhered to the Preferred Reporting Items for Systematic Reviews and Meta-Analyses (PRISMA) guidelines [14]. A detailed literature review was conducted to describe the chemistry, pharmacology, clinical properties and pharmacologic claims made against African Potato.

\section{Identification of articles}

The literature search was done using PubMed, Cochrane Controlled Trials Register (CENTRAL) and Google Scholar. These databases were searched independently for relevant literature through October 2018. The search was re-run on 16 May 2019 and no new studies were found. Other research material was obtained from open searches using Google. The following MeSH (Medical Subject Headings) terms and keywords were used, but not limited to: "African Potato" OR "hypoxis" OR "hemerocallidea" OR "rooperol". An example of the search details in PubMed is given below: "African Potato"[All Fields] OR 
"hypoxis"[MeSH Terms] OR "hemerocallidea"[All Fields] OR "rooperol" (Supplementary Concept).

\section{Eligibility criteria}

The material that described the chemistry, uses and pharmacology of hypoxis hemerocallidea were included. Other plant species were not included. The "sort by relevance" feature in Google Scholar was used; and where applicable, current articles and websites were selected for discussion. We did not restrict publication date. Clinical trials were included in the search. Table 1 shows the inclusion/ exclusion criteria.

\section{Results and discussion}

Thirty-three articles were used for data collection. Figure 1 shows the flow diagram for the data collection. The general characteristics of the articles and the data extracted are shown in Table 2.

\section{Pharmacology and chemistry}

Hypoxis species have been reported to produce a variety of phytoglycosides; extensive research has been focused on the norlignan diglycoside hypoxoside and its aglycon rooperol. The main glycoside that is isolated from the Hypoxis spp. is hypoxoside [21]. Following oral administration, hypoxoside is metabolized in the gut to rooperol by $\beta$-glucosidase. There are two glucose units at the ends of two benzene rings on hypoxoside [10]. These units are oxidized by $\beta$-glucosidase to form the aglycone, rooperol. The enzyme $\beta$-glucosidase is found mostly in the gastrointestinal tract (GIT) and is released by rapidly dividing cancer cells. Rooperol is the biologically active compound that is associated with claims of medicinal properties [11].

Other constituents in hypoxis include various sterols and their glycosides, and these may have biological importance. $H$. hemerocallidea contains $\beta$-sitosterol (BSS), $\beta$-sitosterol glucoside (BSSG), campesterol and stigmasterol [39]. These plant sterols (phytosterols) have biologic roles in animal and human health. Phytosterols are incorporated into functional foods and inhibit the absorption of cholesterol from the diet. They also have prophylactic and therapeutic uses in hypercholesterolemia, cardiovascular disease and atherosclerosis [40].

Among the phytosterols, $\beta$-sitosterol and its glycoside have been studied most for their pharmacological effects [41]. In vitro, the combination of BSS and BSSG indicated anti-inflammatory effects mediated by the inhibition of interleukin 6 and tumor necrosis factor secretion. The anti-inflammatory effects of the mixture relieved rheumatoid arthritis in humans. Another small pilot study reported that the BSS/ BSSG mixture resulted in significant improvement in allergic rhinitis/sinusitis after 12 weeks and this was attributed to immunological changes in the cytokine profiles produced by lymphocytes [40]. In vitro, phytosterols can affect different levels of tumor development and they have immune-modulating properties [41]. Phytosterols initiated programmed cell death (apoptosis) in human colon cancer, breast cancer, and prostate cancer. The probable mechanism was the activation of the protein phosphatase A2 pathway and the sphingomyelin cycle [22].

Rat models suggest that phytosterols may offer protection against breast, colon and prostate cancer [39]. In Phase I clinical trials, BSS has proven to be safe [15]. Sitosterols are poorly absorbed from the gastrointestinal tract. In humans, oral bioavailability is no more than $5 \%$ and it is $9 \%$ in dogs [23]. However, with advanced formulation technology many targeted drug delivery systems may provide alternative approaches for compounds with low bioavailability [45]. If successful, targeted delivery systems could aid in the delivery of phytosterols to facilitate clinical trials. An important knowledge gap is the drug interactions that may occur in immunocompromised patients who require many other medications (polypharmacy).

In another study, domestic cats were infected with a model of HIV. Cats treated with phytosterols maintained

Table 1 Inclusion/ exclusion criteria

\begin{tabular}{|c|c|c|}
\hline Criteria & Inclusion & Exclusion \\
\hline $\begin{array}{l}\text { Study } \\
\text { design }\end{array}$ & Clinical trial, quantitative, qualitative and mixed methods study, systematic/ narrative reviews & None \\
\hline Population & All ages, all species & None \\
\hline Location & Any country & None \\
\hline Date & Studies available up to October 2018. & $\begin{array}{l}\text { Studies published } \\
\text { after October } 2018\end{array}$ \\
\hline Language & English or translated to English & $\begin{array}{l}\text { Not translated to } \\
\text { English }\end{array}$ \\
\hline $\begin{array}{l}\text { Research } \\
\text { focus }\end{array}$ & Describing the chemistry, uses and pharmacology of African potato (hypoxis genus) & $\begin{array}{l}\text { Describing other plant } \\
\text { species or genus }\end{array}$ \\
\hline $\begin{array}{l}\text { Document } \\
\text { type }\end{array}$ & $\begin{array}{l}\text { Full text article of research articles, clinical trials, systematic reviews, scientific reports, ethnopharmacological } \\
\text { studies, ethnobotanical surveys, commentaries, case reports, conference proceedings. }\end{array}$ & $\begin{array}{l}\text { Full text of document } \\
\text { not available }\end{array}$ \\
\hline
\end{tabular}




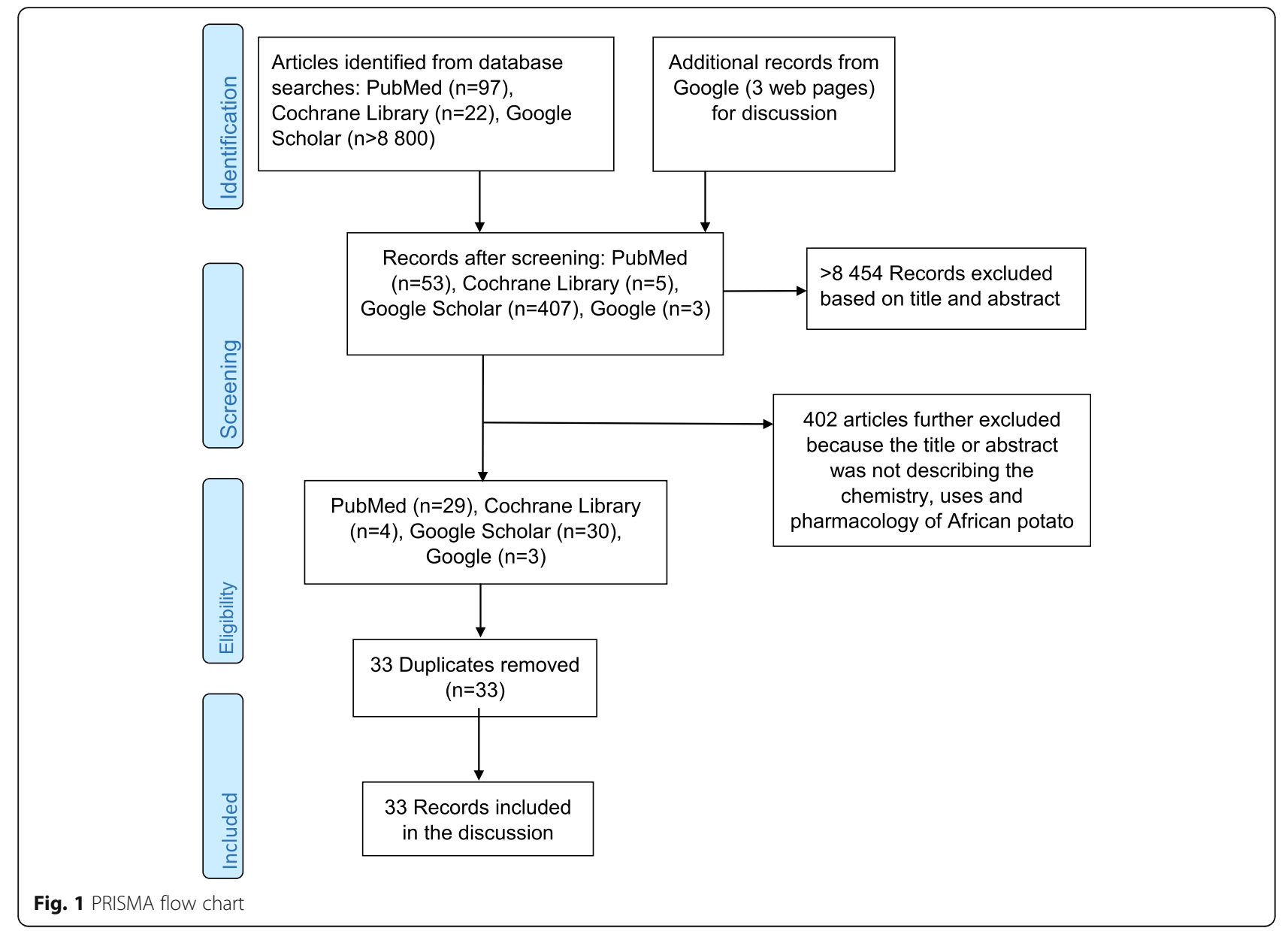

stable CD4 cell counts compared to placebo; the mortality between the two groups was significantly different [24]. In humans, an open-label study compared the efficacy of BSS/ BSSG with placebo in HIV infected treatment-naïve patients. During the time of the study, antiretroviral treatment (ART) was not affordable to most patients. Within 12 months, patients with $>500$ CD4 cells/ $\mu \mathrm{l}$ at baseline maintained their CD4 cell count and plasma viral loads were significantly decreased. Those with advanced HIV at baseline $(<200$ CD4 cells/ $\mu$ l) still had disease progression. Patients in the BSS/ BSSG arm maintained a favorable $\mathrm{T}_{\mathrm{H} 1}$ response and their cell-mediated immunity was likely to be responsible for their response [20]. These findings concur with clinical trials that were conducted later that early initiation of ART delays the time to AIDS events [46]. In addition, there should be more research on herbs that enhance immune function in immunocompromised individuals to slow the progression of the disease. Again, due to polypharmacy, possible drug-herb interactions should be considered. Phytosterols are associated with faster clinical recovery in pulmonary tuberculosis [16] and possess anti-inflammatory, wound healing, analgesic, anti-helminthic, anti-mutagenic, anti-oxidant, neuroprotective and anti-diabetic properties [41].

There is limited knowledge on other secondary metabolites of hypoxis. As of 17 October 2018, a literature search found one study in Zimbabwe that compared the phytochemical profiles and cytotoxicity of four species of hypoxis. These were $H$. hemerocallidea, $H$. rigidula, H. galpinii and H. obtuse. Although this study did not quantify the phytochemicals, corm extracts of all four species indicated the presence of terpenoids, saponins, cardiac glycosides, tannins and reducing sugars. All species screened negative for alkaloids, flavonoids, and anthraquinones [1]. In other plant species, these phytochemicals are claimed to have curative activity against several pathogens [47]. The phytochemicals identified in this study can be attributed to the biologic activities of hypoxis. Terpenoids have antimicrobial and antioxidant properties and they are explored as cytotoxic and antineoplastic agents [48]. Saponins from plant sources have various pharmacologic effects like antimicrobial, anticancer, anthelmintic, antioxidant, antidiabetic, anticonvulsant, analgesic, antispasmodic, hypocholesterolemic, antitussive and cytotoxic activities 
Table 2 General characteristics of included studies

\begin{tabular}{|c|c|c|c|}
\hline $\begin{array}{l}\text { Study } \\
\text { number }\end{array}$ & Study design & Author, year [reference] & Data extracted \\
\hline 1. & Clinical trial & Albrecht et al., 1995 [15] & $\begin{array}{l}\text { Safety of } \beta \text {-sitosterol; dose and metabolic pathway of } \\
\text { hypoxoside }\end{array}$ \\
\hline 2. & & Donald et al., 1997 [16] & Pharmacological effects of phytosterols \\
\hline 3. & & Mogatle et al., 2008 [17] & African potato drug interactions \\
\hline 4. & & Gwaza et al., 2013 [18] & African potato drug interactions \\
\hline 5. & & Berges et al., 1995 [19] & Clinical properties, the dosage of $\beta$-sitosterol \\
\hline 6. & $\begin{array}{l}\text { Pilot study, open-label } \\
\text { intervention }\end{array}$ & Bouic et al., 2001 [20] & Pharmacological effects of $\beta$-sitosterol \\
\hline 7. & Quantitative, experimental & Boukes GJ et al., 2010 [21] & Pharmacology \\
\hline 8. & & Awad et al., 2000 [22] & Mechanism of action \\
\hline 9. & & Bouic et al., 1996 [23] & Pharmacology and bioavailability of $\beta$-sitosterol \\
\hline 10. & & Lamprecht et al., 2000 [24] & $\beta$-sitosterol and the glucoside mixture improving CD4 count \\
\hline 11. & & Albrecht et al., 1995 [25] & $\begin{array}{l}\text { Mechanism of action, metabolism and pharmacokinetics of } \\
\text { hypoxoside }\end{array}$ \\
\hline 12. & & Kruger et al., 1994 [26] & Metabolism of hypoxoside \\
\hline 13. & & Nair et al. 2007, [27] & Metabolism of African potato \\
\hline 14. & & Gwaza et al., 2009 [28] & Drug interactions of hypoxis extracts \\
\hline $15-22$. & $\begin{array}{l}\text { Experimental preclinical } \\
\text { (in vivo) }\end{array}$ & As shown in Table 3 & Pharmacologic activities of Africa Potato in different species \\
\hline 23. & Qualitative screening & Zimudzi C, 2014 [1] & Chemistry \\
\hline 24. & & Nair et al., 2006 [37] & Dosage of African potato \\
\hline 25. & Systematic review & Ncube et al., 2013 [38] & $\begin{array}{l}\text { Uses of African potato and dosage forms (and strengths) } \\
\text { available }\end{array}$ \\
\hline 26. & Narrative review & Drewes SE et al., 2008 [10] & Chemistry, ethnopharmacological properties \\
\hline 27. & & Mills E et al., 2005 [11] & Pharmacology, chemistry, ethnopharmacological properties \\
\hline 28. & & Bouic 2001, [39] & Chemistry and pharmacological uses \\
\hline 29. & & Ling et al.,1995 [40] & Pharmacological uses, mechanism of action of phytosterols \\
\hline 30. & & Saeidnia et al., 2014 [41] & Pharmacological effects \\
\hline 31. & Not applicable - Website & Natures Health website, [42] & Dosage of African potato capsules \\
\hline 32. & & $\begin{array}{l}\text { Green Herbs \& Nutrition's Stores } \\
\text { website, [43] }\end{array}$ & Dosage of African potato capsules \\
\hline 33. & & Puer Orijins catalogue, [44] & Other dosage forms available \\
\hline
\end{tabular}

[49]. Cardiac glycosides inhibit the $\mathrm{Na}^{+} / \mathrm{K}^{+}$pump thus slow the heart rate and increase the contractility of the heart muscle. Although they improve the cardiac output and heart function, their use is associated with toxicity because of a narrow therapeutic index [50]. Tannins have anti-oxidative activities; due to these properties, they are anti-carcinogenic and anti-mutagenic. In addition, tannins have antimicrobial properties, accelerate blood clotting, reduce blood pressure, decrease serum lipid levels and modulate immune responses [51]. Reducing sugars have a regulatory role in plants, controlling their growth and development to provide resistance against diseases [52].

It is well known that combining several bioactive compounds result in a greater pharmacological response than using the single components [53]. With traditional medicines, isolating the desired phytochemicals and combining them can result in achieving the desired pharmacological response. More laboratory and clinical studies with hypoxis are required in this area of research.

\section{Preclinical pharmacologic activities (Table 3) Absorption and metabolism}

After oral administration, hypoxoside is not absorbed and undergoes enzymatic hydrolysis. In the circulatory system, hypoxoside is converted to rooperol (Fig. 2) by $\beta$ glucosidase. Intragastric administration of hypoxoside in mice resulted in deconjugation by bacterial $\beta$-glucosidase to form rooperol in the colon. In mice, neither hypoxoside nor rooperol metabolites were detectable in the blood. 
Table 3 Preclinical (in vivo) Pharmacologic Activities of Africa Potato in different formulations

\begin{tabular}{|c|c|c|c|c|}
\hline Species & Dose and administration & Parameters assessed & Conclusions & Reference \\
\hline \multirow[t]{2}{*}{ Male rats } & $\begin{array}{l}\text { Acute testing: } 0.45 ; 0.90 \text { and } \\
1.8 \mathrm{mg} / \mathrm{kg} \text { infusion }\end{array}$ & \multirow[t]{2}{*}{$\begin{array}{l}\text { Urine volume and total urinary outputs of } \\
\text { creatinine, sodium, and potassium. }\end{array}$} & \multirow{2}{*}{$\begin{array}{l}\text { Increased plasma creatinine concentration, } \\
\text { renal fluid, and electrolyte retention and } \\
\text { reduced GFR compared with controls, APE } \\
\text { may impair renal function. }\end{array}$} & \multirow[t]{2}{*}{ [29] } \\
\hline & $\begin{array}{l}\text { Chronic: APE } 30 \text { mg/ kg } \\
\text { infusion }\end{array}$ & & & \\
\hline \multirow[t]{2}{*}{$\begin{array}{l}\text { Healthy } \\
\text { mice }\end{array}$} & \multirow[t]{2}{*}{$\begin{array}{l}\text { Corm aqueous extract (100- } \\
800 \text { mg/kg i.p.) }\end{array}$} & $\begin{array}{l}\text { Effect against pentylenetetrazole-, picrotoxin- } \\
\text { and bicuculline-induced seizures. }\end{array}$ & $\begin{array}{l}\text { APE has anticonvulsant activity possibly by } \\
\text { enhancing GABAergic neurotransmission } \\
\text { and/or action in the brain. }\end{array}$ & \multirow[t]{2}{*}[30]{} \\
\hline & & $\begin{array}{l}\text { Phenobarbitone and diazepam used as the } \\
\text { reference. }\end{array}$ & $\begin{array}{l}\text { Doses of } \geq 400 \mathrm{mg} / \mathrm{kg} \text { resulted in dose- } \\
\text { related sedation and drowsiness. }\end{array}$ & \\
\hline \multirow{5}{*}{$\begin{array}{l}\text { Rats and } \\
\text { guinea-pigs }\end{array}$} & \multirow{5}{*}{$\begin{array}{l}\text { Corm aqueous extract } 25-400 \\
\mathrm{mg} / \mathrm{ml} \text { orally }\end{array}$} & \multirow{5}{*}{$\begin{array}{l}\text { Uterine horns isolated from rats and guinea- } \\
\text { pigs. }\end{array}$} & Extract showed uterolytic activity & \multirow[t]{5}{*}{ [31] } \\
\hline & & & $\begin{array}{l}\text { Inhibited the amplitude and sometimes, } \\
\text { the frequency of the spontaneous, } \\
\text { rhythmic contractions. }\end{array}$ & \\
\hline & & & Relaxed pregnant uterine muscles. & \\
\hline & & & $\begin{array}{l}\text { Mechanism is unknown, probably } \\
\text { mediated through a non-specific spasmo- } \\
\text { lytic mechanism. }\end{array}$ & \\
\hline & & & $\begin{array}{l}\text { Extracts to } 2.5 \mathrm{~g} / \mathrm{kg} \text { did not produce any } \\
\text { toxic manifestations or mortalities. }\end{array}$ & \\
\hline \multirow{4}{*}{$\begin{array}{l}\text { Newborn } \\
\text { suckling } \\
\text { rats }\end{array}$} & \multirow{4}{*}{$\begin{array}{l}\text { African Potato ethanol or } \\
\text { aqueous extract }(50 \mathrm{mg} / \mathrm{kg} \text { and } \\
\text { a high dose of } 200 \mathrm{mg} / \mathrm{kg}) \text { via a } \\
\text { stomach tube }\end{array}$} & \multirow[t]{4}{*}{$\begin{array}{l}\text { Viscera removed for gross and microscopic } \\
\text { morphometric measurements. }\end{array}$} & $\begin{array}{l}\text { At a low dose, the mean weight gain was } \\
\text { significantly increased. }\end{array}$ & \multirow[t]{4}{*}[32]{} \\
\hline & & & $\begin{array}{l}\text { The high dose of aqueous extract } \\
\text { increased the weight of the caeca. }\end{array}$ & \\
\hline & & & $\begin{array}{l}\text { The low dose of alcohol extract reduced } \\
\text { the pancreas weight. }\end{array}$ & \\
\hline & & & No adverse effects, no signs of pathology. & \\
\hline \multirow[t]{3}{*}{$\begin{array}{l}\text { Healthy rats } \\
\text { and mice }\end{array}$} & \multirow[t]{3}{*}{$\begin{array}{l}\text { Corm aqueous extract (APE, } \\
50-400 \mathrm{mg} / \mathrm{kg} \text {, orally) }\end{array}$} & $\begin{array}{l}\text { Effect against castor oil-induced diarrhea, } \\
\text { entero-pooling, intestinal transit, and intes- } \\
\text { tinal fluid. }\end{array}$ & \multirow{2}{*}{$\begin{array}{l}\text { APE delayed the onset of copious diarrhea, } \\
\text { reduced number, and weight of wet } \\
\text { stools, inhibited the severity of diarrhea, } \\
\text { inhibited intestinal transit and delayed } \\
\text { gastric emptying. }\end{array}$} & \multirow[t]{3}{*}{ [33] } \\
\hline & & \multirow[t]{2}{*}{$\begin{array}{l}\text { Atropine and loperamide used as positive } \\
\text { controls. }\end{array}$} & & \\
\hline & & & $\begin{array}{l}\text { Speculated mechanism that the sterols, } \\
\text { stanols and sterolins, especially rooperol } \\
\text { and } \beta \text {-sitosterol are responsible for antimo- } \\
\text { tility, spasmolytic and anticholinergic } \\
\text { effects. }\end{array}$ & \\
\hline $\begin{array}{l}\text { Healthy } \\
\text { mice }\end{array}$ & $\begin{array}{l}\text { AP methanolic extract ( } 15 \mathrm{mg} \\
\text { of extract orally) }\end{array}$ & $\begin{array}{l}\text { After Brachyspira hyodysenteriae -induced } \\
\text { typhlocolitis; weight loss, gross and } \\
\text { histological lesions, MPO activity, and } \\
\text { intestinal epithelial proliferation were } \\
\text { evaluated. }\end{array}$ & $\begin{array}{l}\text { AP extract reduced weight loss, the } \\
\text { severity of typhlocolitis, inflammation and } \\
\text { intestinal epithelial proliferation. }\end{array}$ & [34] \\
\hline Albino rats & $\begin{array}{l}\text { Aqueous corm decoction ( } 10 \\
\mathrm{ml} / \mathrm{kg} \text { ) and } 20 \mathrm{ml} / \mathrm{kg} \text { orally }\end{array}$ & $\begin{array}{l}\text { Parameters assayed were TBARS, SGOT, SGPT, } \\
\text { GSH, ascorbic acid, tocopherol, superoxide } \\
\text { dismutase and glutathione peroxidase in } \\
\text { RBC and in the liver. }\end{array}$ & $\begin{array}{l}\text { Protection from oxidative stress generated } \\
\text { by chloroquine, strengthen the antioxidant } \\
\text { system under normal conditions. }\end{array}$ & [35] \\
\hline \multirow{3}{*}{$\begin{array}{l}\text { STZ - } \\
\text { Induced } \\
\text { diabetic } \\
\text { male Wistar } \\
\text { rats }\end{array}$} & \multirow[t]{3}{*}{$\begin{array}{l}\text { Aqueous solution }(200 \mathrm{mg} / \mathrm{kg} \\
\text { or } 800 \mathrm{mg} / \mathrm{kg}) \text { administered } \\
\text { orally }\end{array}$} & \multirow[t]{3}{*}{$\begin{array}{l}\text { Oxidative stress biomarkers, hepatic injury, } \\
\text { and selected biomarkers in the liver and } \\
\text { kidney. }\end{array}$} & $\begin{array}{l}\text { Both dosages showed significant } \\
\text { antihyperglycemic effects, both showed } \\
\text { antioxidant effects in the liver tissue. }\end{array}$ & \multirow[t]{3}{*}{ [36] } \\
\hline & & & $\begin{array}{l}\text { At higher concentration, the activity of } \\
\text { liver enzymes was increased and a } \\
\text { negative effect on the kidneys was } \\
\text { observed. }\end{array}$ & \\
\hline & & & $\begin{array}{l}\text { Lower concentrations ameliorated liver } \\
\text { injury. }\end{array}$ & \\
\hline
\end{tabular}

AP African Potato, APE African Potato aqueous extract, i.p. Intraperitoneal, GFR glomerular filtration rate, GSH reduced glutathione, MPO myeloperoxidase, $R B C$ red blood cells, SGOT serum glutamate oxaloacetate transaminase, SGPT serum glutamate pyruvate transaminase, STZ streptozotocin, TBARS thiobarbituric acid reactive substance 




Hypoxoside(1)

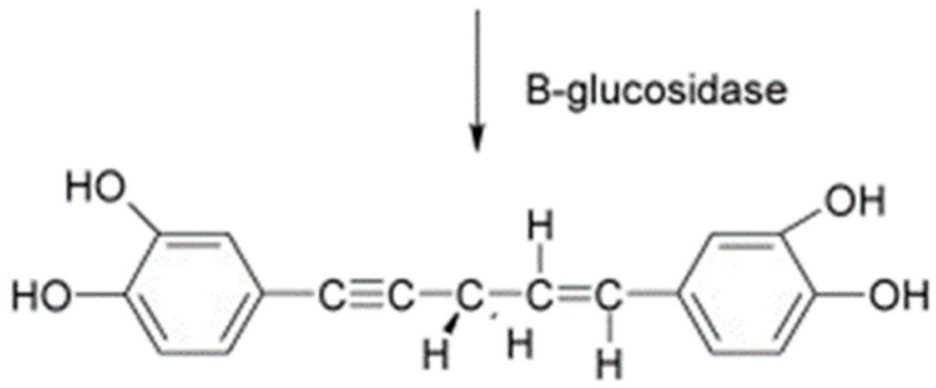

Rooperol (2)

Fig. 2 Structures of hypoxoside and rooperol [10]

There were only Phase II metabolites of sulphates and glucuronides present in the bile of mice, rats, and dogs [25]. However, in humans and baboons, these metabolites appear in the plasma at relatively high concentrations [26]. The end products of the hydrolysis were rooperol, dehydroxyrooperol and bis-dehydroxyrooperol [15]. The metabolic pathway of African Potato is illustrated in Fig. 3.

The presence of rooperol was analyzed in faeces and urine in humans. After administration of $1 \mathrm{~g}$ of hypoxoside, rooperol was present in faeces at 6-h post-dosing. No rooperol was detected in urine after $24 \mathrm{~h}$. Some of the rooperol was absorbed from the colon and some were eliminated in the faeces. The formation and absorption of rooperol was a zeroorder saturable process [15].

\section{Drug interaction studies}

The effects on cytochrome P450 (CYP) - mediated metabolism of African Potato were studied in vitro using cell lines. The African Potato extracts demonstrated inhibitory effects on CYP3A4-, 3A5- and CYP19-mediated metabolism and high induction of P-glycoprotein (P-gp) as compared to ritonavir, the positive control [27]. Another study evaluated the effect of hypoxis on drug interactions in vitro using human liver microsomes. In methanol extracts, at least 95\% inhibitory effects were observed for CYP1A2, 2C9, 3A4 and 2D6 compared to positive controls. Aqueous hypoxis extracts led to moderate CYP inhibition. The extracts of hypoxis indicated no significant inhibition of P-gp although the authors suggested some effect on P-gp was possible at higher concentrations than those used in the assays [28].

These in vitro results served as the foundation for in vivo interaction studies for African Potato. A study conducted in South Africa determined the effect of African Potato on efavirenz pharmacokinetics. Ten healthy volunteers participated in this singledose, two-phase sequential study over 31 days [17]. Efavirenz is a non-nucleoside reverse transcriptase inhibitor (NNRTI) effective against HIV-1. It is the backbone of combination antiretroviral therapy (cART) in Africa and is mainly metabolized by CYP2B6 and to a lesser extent CYP3A4 [54]. For the South African study, the following parameters were used to determine interactions: $\mathrm{AUC}_{0-48}, \mathrm{C}_{\max }, \mathrm{T}_{\max }$, $\mathrm{T}_{1 / 2}$, and $\mathrm{K}_{\mathrm{el}}$. The results indicated that the $90 \%$ confidence intervals $(\mathrm{CI})$ for $\mathrm{C}_{\max }$ and $\mathrm{AUC}_{0-48}$ were within the limits of $80-125 \%$ interval. Thus, the investigators concluded that the African Potato did not alter efavirenz pharmacokinetics. The investigators recommended that further research is needed to investigate African Potato and other antiretrovirals especially those that are P-gp substrates or CYP3A4 metabolites [17]. Although this study had a clear and concise methodology, the sample size calculations were not well explained, especially considering the intra-individual variability of the $\mathrm{AUC}$ and $\mathrm{C}_{\max }$ for efavirenz. In addition, single-dose studies do not 


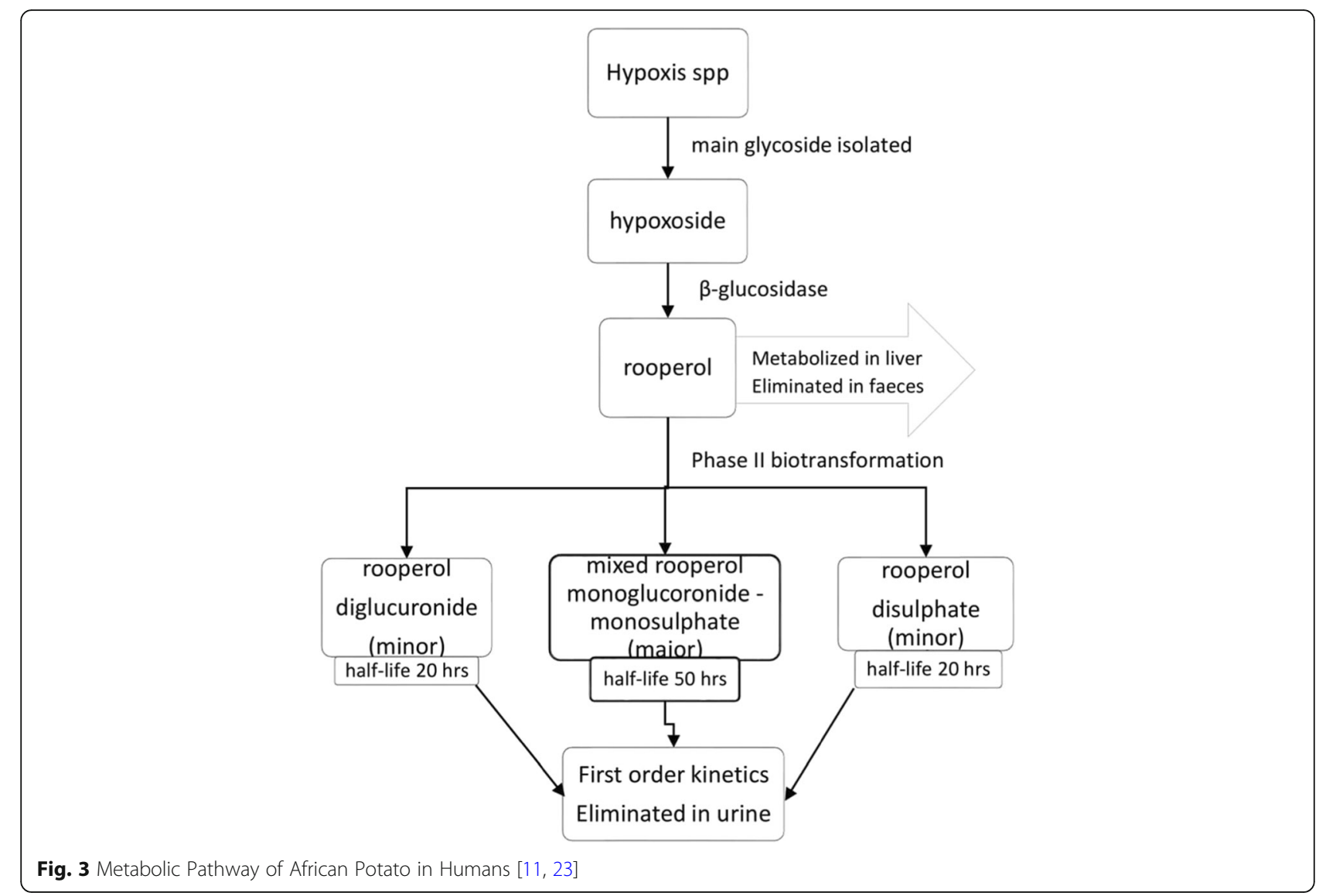

consider induction that occurs during chronic dosing.

Another study investigated the effect of African Potato on the steady-state pharmacokinetics of ritonavirboosted lopinavir (LPV/r). Lopinavir/ ritonavir is a potent HIV protease inhibitor combination that is used with other antiretrovirals for the treatment of HIV infection. Lopinavir (LPV) increases ritonavir (RTV) concentrations through inhibition of CYP3A4. LPV is metabolized primarily by hepatic and gastrointestinal CYP3A4. They hypothesized that since in vitro studies indicate that extracts of African Potato have a significant inhibitory effect on CYP3A4 this could lead to an increase in exposure, associated with an increased cholesterol/ diabetes risk. This study was an open-label, two-period; fixed sequence, crossover pharmacokinetic drug interaction study. Sixteen healthy, HIV-seronegative adult volunteers between 18 to 60 years were enrolled. The following parameters were used to determine interactions: AUC $_{0-18}, C_{\max }, C_{\text {trough }}, T_{\max }, T_{1 / 2}, C_{F}$ and $K_{e l}$. Results indicated that steady-state plasma concentrationtime profiles of LPV with and without African Potato were similar as reflected by the $90 \%$ confidence intervals that were within the $80-125 \%$ limit. The effect on ritonavir was not analyzed in this study. Total cholesterol and triglycerides were elevated but within limits during LPV/r treatment [18]. The investigators concluded that African Potato had no significant effect on the steady-state pharmacokinetics of LPV. This study was well designed although the results cannot be generalized to other populations. It would have been ideal to use participants from Africa, where African Potato use is prevalent. Clinical studies involving African Potato or its constituents are summarized in Table 4.

Both the South African and USA studies were testing African Potato in healthy individuals. Literature reveals that African Potato is widely used for its immuneenhancing properties in HIV infected individuals [11]. Since African Potato has shown to be safe and well tolerated in healthy individuals, further research should focus on people living with HIV/AIDS. It would also be necessary to study the interactions of African Potato in HIV infected individuals taking other antiretroviral drugs.

\section{Dosage recommendations}

Traditionally, African Potato is cut into cubes or shredded and boiled in water for $20 \mathrm{~min}$ before the decoction 
Table 4 Clinical Studies involving African Potato and/ its Constituents

\begin{tabular}{|c|c|c|c|c|c|}
\hline Population & Study Design & Dose and administration & Parameters Assessed & Major Findings & Reference \\
\hline $\begin{array}{l}16 \text { ( } 12 \text { males, } 4 \text { females) } \\
\text { healthy HIV-seronegative } \\
\text { adults, USA. The median } \\
\text { age (range) was } 28 \text { yrs. } \\
\text { (19-53 yrs). Median weight } \\
\text { (range) was } 78 \mathrm{~kg} \text { (53-96 } \\
\mathrm{kg} \text { ) }\end{array}$ & $\begin{array}{l}\text { An open-label, two- } \\
\text { period, fixed se- } \\
\text { quence, cross-over } \\
\text { pharmacokinetic drug } \\
\text { interaction study. }\end{array}$ & $\begin{array}{l}\text { LPV/r } 400 / 100 \mathrm{mg} \text { tablet } \\
\text { orally twice a day for } 14 \\
\text { days, then LPV/r with } \\
\text { African potato ( } 15 \mathrm{mg} / \mathrm{kg} \\
\text { hypoxoside) orally once } \\
\text { daily for } 7 \text { days. }\end{array}$ & $\begin{array}{l}\text { Plasma samples collected } \\
\text { on day } 14 \text { after } \mathrm{LPV} / \mathrm{r} \\
\text { alone and day } 21 \text { after } \\
\mathrm{LPV} / \mathrm{r} \text { plus African potato } \\
\text { for AUC, } C_{\text {max }} \mathrm{C}_{\text {trough, }} \mathrm{T}_{\max ,} \\
\mathrm{T}_{1 / 2,}, \mathrm{~K}_{\mathrm{el}}, \mathrm{CL}_{\mathrm{F}} \text {. Time of } \\
\text { collection: within } 1 \mathrm{~h} \\
\text { before dosing and at } 1,2 \text {, } \\
4,6,8 \text {, and } 12 \mathrm{~h} \text { post-dose } \\
\text { for both phases. }\end{array}$ & $\begin{array}{l}\text { African potato combined } \\
\text { with LPV/r was not } \\
\text { associated with any } \\
\text { change in LPV/r AUC, } C_{\text {max, }} \\
C_{\text {trough. No serious adverse }} \\
\text { events observed. }\end{array}$ & [18] \\
\hline
\end{tabular}

10, (9 black, 1 white) healthy HIV-negative males. The mean age (range) was 23 yrs. (19-27 yrs).

\section{A single-dose, two-} phase sequential study.
Efavirenz $600 \mathrm{mg}$ tablet orally on day 1 , then from day 16 , a traditionally prepared African Potato decoction $(15 \mathrm{mg} / \mathrm{kg}$ of hypoxoside) given daily until day 30 . On day 28 efavirenz $600 \mathrm{mg}$ tablet was given orally.

A double-blinded, randomized, placebocontrolled trial to evaluate the effects $\begin{array}{ll}\text { weight } 49 \pm 6 \mathrm{~kg} \text { ) and } 18 & \text { of BSSG and BSS in } \\ \text { in the placebo group } & \text { the treatment of PTB }\end{array}$ $\begin{array}{ll}\text { weight } 49 \pm 6 \mathrm{~kg} \text { ) and } 18 & \text { of BSSG and BSS in } \\ \text { in the placebo group } & \text { the treatment of PTB }\end{array}$ (mean age $37 \mathrm{yrs}$. and weight $51 \pm 9 \mathrm{~kg}$ ).

\section{4 patients with} histologically proven squamous, large-cell, or adenocarcinoma, South Africa.
A randomized, open, single-dose study of the pharmacokinetic behavior of hypoxoside in patients with lung cancer.
Randomized to receive either the active capsule with sitosterols $(0.2 \mathrm{mg}$ BSSG, 20 mg BSS, $200 \mathrm{mg}$ talcum) or placebo (200

mg talcum). One capsule three times daily together with their standard antituberculosis regimen (isoniazid, rifampicin, pyrazinamide) for 6 months.

Three groups with dosage levels of 1600 , or 2400 , or $3200 \mathrm{mg}$ standardized hypoxis plant extract (200 mg capsules). The first 6 patients in the multipledose study took 4 capsules 3 times daily for 11 days.
200 male patients with symptomatic BPH not on any treatment, Germany.
A randomized, double-blind, placebo-controlled multicenter study.
Randomized to receive either 20 mg BSS capsule (including $01 \mathrm{mg} \mathrm{BSSG}$ ) three times per day or placebo.
Phase 1 started on day 1 and phase 2 on day 29 , each phase lasting 3 days. Plasma samples were collected before dosing and at $0.5,1,1.5,2,2.5,3$, $3.5,4,5,6,8,12,18,24,36$ and $48 \mathrm{~h}$ after dosing. Samples were assayed for AUC, $C_{\max }, T_{\max }, T_{1 / 2}$ and $\mathrm{K}_{\mathrm{el}}$.

Sputum culture positivity, chest radiography, weight gain, Mantoux test response, routine hematology and liver function. PTB was confirmed by sputum smear microscopy for acidfast bacilli and culture for Mycobacterium tuberculosis.

Serum samples were collected at regular intervals up to $75 \mathrm{~h}$ after single doses for the detection of hypoxoside metabolites. In the multiple-dose study, blood was drawn before the first dose each day. Pharmacokinetic parameters of the major metabolites were analyzed using different models in the NONMEM program.

The endpoints were a difference of modified Boyarsky score (recorded monthly) for 6 months, changes in IPSS, urine flow, and prostate volume (every 3 months.)

The geometric mean ratios of $C_{\max }$ and $A U C$ were within the limits of 80 $125 \%$. African potato did not alter the pharmacokinetics of efavirenz. No serious adverse effects were noted.

Compared to placebo, there was significant weight gain, higher lymphocyte and eosinophil counts in PTB patients receiving sitosterols in addition to antituberculosis therapy. 
day was found to be therapeutic [19]. According to literature, an oral dose of $15 \mathrm{mg} / \mathrm{kg} /$ day is reportedly therapeutic [18]; however, it is unknown whether this dose is effective for all the claims against African Potato. Other sources state that $2400 \mathrm{mg}$ taken daily is therapeutic [15]. Standardized capsules are available online which contain from 300 to $350 \mathrm{mg}$ hypoxis hemerocallidea. The doses for these formulations vary; some stating one capsule twice daily and some stating two tablets 3 times a day for the first 5 days, then one tablet 3 times a day $[42,43]$. In South Africa, herbal formulations of African Potato are mainly used to enhance the immune system. The herbal formulations are available as capsules, tonics, creams and tinctures containing 300-500 mg hypoxis hemerocallidea or sterols/ sterolins [38]. With the many claims against the plant, it is unknown if this dose is a standard dose. Besides capsules, other formulations available include powders, face creams, night cream, nasal spray, soap, tissue oil, toner and exfoliator [44]. There is a knowledge gap in the therapeutic dosage for herbal medicines since most of the recommended doses are based on anecdotal information [11]. Furthermore, there is limited research in clinical trials using herbal medicines [55]. This is an area of research that could be explored further, even with African Potato.

\section{Conclusion}

African Potato rootstock (corm) is used to treat a wide variety of ailments. It is mainly used as an immunostimulant in people living with HIV/ AIDS. The active components include rooperol, which is an antioxidant and several phytosterols. The mechanisms of action for all the pharmacological actions are unknown. Some of the pharmacological actions were reported in older studies and there is a need for studies to substantiate the claims using current technology and with the application of systems pharmacology. African Potato is of intense commercial and scientific interest and more clinical trials should be performed to evaluate dosage regimens. The plant shows a good safety profile although there are no studies that have demonstrated safety in children, pregnant and lactating women. More research is required to substantiate the many claims that recommend the use of African Potato. There are important research gaps on the possible interactions with conventional drugs, especially those used in HIV/AIDS.

\section{Supplementary information}

Supplementary information accompanies this paper at https://doi.org/10. 1186/s12906-020-02956-X.

Additional file 1. PRISMA 2009 checklist.

\section{Abbreviations}

AIDS: Acquired immunodeficiency syndrome; AP: African Potato; APE: African Potato aqueous extract; ART: Antiretroviral treatment; AUC: Area under the concentration-time curve within a dosing interval; BSS: $\beta$-sitosterol; BSSG: $\beta$ sitosterol glucoside; CART: Combination antiretroviral therapy; $\mathrm{CL}_{\mathrm{F}}$ : Apparent clearance; $C_{\text {max }}$ : Maximum concentration following dose administration; $C_{\text {trough: }}$ Plasma concentration at the end of the dosing interval; CYP: Cytochrome P450; GFR: Glomerular filtration rate; GIT: Gastrointestinal tract; GSH: Reduced glutathione; $\mathrm{K}_{\mathrm{e}}$ : Elimination rate constant; HIV: Human immunodeficiency virus; i.p: Intraperitoneal; LPV/r: Ritonavir-boosted Iopinavir; LPV: Lopinavir; MPO: Myeloperoxidase; NNRTI: Non-nucleoside reverse transcriptase inhibitor; P-gp: P-glycoprotein; PLWHA: People living with HIV/ AIDS; PRISMA: Preferred Reporting Items for Systematic Reviews and Meta-Analyses; RBC: Red blood cells; RTV: Ritonavir; SARS: Severe acute respiratory syndrome; SGOT: Serum glutamate oxaloacetate transaminase; SGPT: Serum glutamate pyruvate transaminase; STZ: Streptozotocin; TBARS: Thiobarbituric acid reactive substance; $T_{\max }$ : Time to reach $C_{\max i}$ $\mathrm{T}_{1 / 2}$ : Half-life; WHO: World Health Organization

\section{Acknowledgements}

Not applicable,

\section{Authors' contributions}

CM conceptualized the research and GM, MG and CN approved the topic. CM conducted the literature review and all authors analysed the results of the review. All authors participated in giving feedback on the manuscript. All authors have read and approved the final manuscript.

\section{Funding}

Celia M. J Matyanga had access to resources for the systematic review and this was supported by Grant Numbers D43TW010313, D43TW007991 and D43TW007991 01A2S1 from the Fogarty International Center. During the peer-review process, Celia M. J Matyanga had access to resources as supported by the L'Oréal-UNESCO For Women in Science Sub-Saharan Africa 2019 Young Talents Award. The content is solely the responsibility of the authors and does not necessarily represent the official views of the Fogarty International Center or the National Institutes of Health or the L'Oréal-

UNESCO For Women in Science Programme.

\section{Availability of data and materials}

All data generated and reviewed during this study was included in this manuscript and in the tables and figures.

\section{Ethics approval and consent to participate}

The data used in this review article was obtained from articles and web pages that were already published in scientific journals. The data was cited, therefore, no ethical approval or consent to participate are applicable.

Consent for publication

Not applicable.

\section{Competing interests}

The authors declare that they have no conflicts of interest that may have inappropriately influenced them in writing this article.

\section{Author details}

1Department of Clinical Pharmacology, College of Health Sciences, University of Zimbabwe, Harare, Zimbabwe. ${ }^{2}$ School of Pharmacy, College of Health Sciences, University of Zimbabwe, Harare, Zimbabwe. ${ }^{3}$ Center for Integrated Global Biomedical Sciences, School of Pharmacy and Pharmaceutical Sciences, University at Buffalo, Buffalo, NY, USA. ${ }^{4}$ Department of Pharmaceutical Technology, School of Industrial Sciences and Technology, Harare Institute of Technology, Belvedere, Harare, Zimbabwe.

Received: 11 February 2019 Accepted: 19 May 2020

Published online: 11 June 2020

References

1. Zimudzi C. African potato (Hypoxis Spp): diversity and comparison of the phytochemical profiles and cytotoxicity evaluation of four Zimbabwean species. JAPS. 2014;4(4):79. 
2. Herbal Medicine Market Size and Forecast, by product (tablets and capsules, powders, extracts), by indication (Digestive Disorders, Respiratory Disorders, Blood Disorders), and Trend Analysis, 2014-2024. Industry insights, Hexa Research Published: September 2017. https://wwwhexaresearchcom/ research-report/global-herbal-medicine-market. Accessed 12 Sept 2018.

3. Tilburt JC, Kaptchuk TJ. Herbal medicine research and global health: an ethical analysis. Bull World Health Organ. 2008;86:594-9.

4. World Health Organization. SARS: Clinical Trials on Treatment Using a Combination of Traditional Chinese Medicine and Western Medicine. 2004 http://apps.who.int/medicinedocs/en/d/Js6170e/. Accessed 27 Sept 2018.

5. Centers for Disease Control and Prevention. 2004. Frequently asked questions about SARS. https://www.cdc.gov/sars/about/faq.html. Accessed 27 September 2018

6. Mudzviti T, Maponga CC, Khoza S, Ma Q, Morse GD. The impact of herbal drug use on adverse drug reaction profiles of patients on antiretroviral therapy in Zimbabwe. AIDS Res Treat. 2012;2012 https://doi.org/10.1155/ 2012/434171.

7. Bepe N, Madanhi N, Mudzviti T, Gavi S, Maponga CC, Morse GD. The impact of herbal remedies on adverse effects and quality of life in HIV-infected individuals on antiretroviral therapy. J Infect Dev Ctries. 2011;5(1):48.

8. Van Wyk BE. A review of commercially important African medicinal plants. J Ethnopharmacol. 2015;176:118-34 https://doi.org/10.1016/j.jep.2015.10.031.

9. Gail H, Tarryn B, Oluwaseyi A, Denver D, Oluchi M, Charlotte VK, de Joop J, Diana G. An ethnobotanical survey of medicinal plants used by traditional health practitioners to manage HIV and its related opportunistic infections in Mpoza, eastern Cape Province, South Africa. J Ethnopharmacol. 2015;171: 109-15. https://doi.org/10.1016/j.jep.2015.05.029.

10. Drewes SE, Elliot E, Khana F, Dhlaminic JTB, Gcumisad MSS. Hypoxis hemerocallidea - not merely a cure for benign prostate hyperplasia. J Ethnopharmacol. 2008;119(3):593-8.

11. Mills E, Cooper C, Seely D, Kanfer I. African herbal medicines in the treatment of HIV: Hypoxis and Sutherlandia. An Overview of Evidence and Pharmacology. Nutr J. 2005;4:19. https://doi.org/10.1186/1475-2891-4-19.

12. Albrecht CF. Hypoxoside: a putative, non-toxic prodrug for the possible treatment of certain malignancies, HIV-infection and inflammatory conditions. In: Proc. 1st International IOCD-Symposium, Victoria Falls, Zimbabwe; 1996. p. 302-7.

13. Viallard JF, Blanco P, André M, Etienne G, Liferman F, Neau D, Vidal E, Moreau JF, Pellegrin JL. CD8+HLA-DR+ T lymphocytes are increased in common variable immunodeficiency patients with impaired memory B-cell differentiation. Clin Immunol. 2006;119(1):51-8 Epub 2006 Jan 18. PubMed PMID: 16413828.

14. Moher D, Liberati A, Tetzlaff J, Altman DG, PRISMA Group. Preferred reporting items for systematic reviews and meta-analyses: the PRISMA statement. J Clin Epidemiol. 2009;62(10):1006-12.

15. Albrecht CF, Kruger PB, Smit BJ, Freestone M, Gouws L, Miller R, van Jaarsveld PP. The pharmacokinetic behaviour of hypoxoside taken orally by patients with lung cancer in a phase I trial. S Afr Med J. 1995;85(9):861-5.

16. Donald PR, Lamprecht JH, Freestone M, Albrecht CF, Bouic PJ, Kotze D, Van Jaarsveld PP. A randomised placebo controlled trial of the efficacy of betasitosterol and its glucoside as adjuvants in the treatment of pulmonary tuberculosis. Int J Tuberc Lung Dis. 1997;1:518-22.

17. Mogatle S, Skinner M, Mills E, Kanfer I. Effect of African potato (Hypoxis hemerocallidea) on the pharmacokinetics of efavirenz. S Afr Med J. 2008; 98(12):945-9.

18. Gwaza L, Aweeka F, Greenblatt R, Lizak P, Huang L, Guglielmo BJ. Coadministration of a commonly used Zimbabwean herbal treatment (African potato) does not alter the pharmacokinetics of lopinavir/ritonavir. Int J Infect Dis. 2013;17(10):e857-61.

19. Berges RR, Windeler J, Trampisch HJ, Senge T. Randomised, placebocontrolled, double-blind clinical trial of $\beta$-sitosterol in patients with benign prostatic hyperplasia. Lancet. 1995;345(8964):1529-32.

20. Bouic PJ, Clark A, Brittle W, Lamprecht JH, Freestone M, Liebenberg RW. Plant sterol/sterolin supplement use in a cohort of south African HIVinfected patients - effects on immunological and virological surrogate markers. S Afr Med J. 2001;91:848-50.

21. Boukes GJ, Daniels BB, Albrecht CF, van de Venter M. Cell survival or apoptosis: rooperol's role as anticancer agent. Oncol Res. 2010;18:365-76.

22. Awad AB, Gan Y, Fink CS. Effect of b-sitosterol, a plant sterol, on growth, protein phospholipase 2A and phospholipid D in LNCaP cells. Nutr Cancer. 2000;36:74-8.
23. Bouic PJ, Etsebeth S, Liebenberg RW, Albrecht CF, Pegel K, Van Jaarsveld PP. Beta-sitosterol and beta-sitosterol glucoside stimulate human peripheral blood lymphocyte proliferation: implications for their use as an immunomodulatory vitamin combination. Int J Immunopharmacol. 1996; 18(12):693-700.

24. Lamprecht JH, Freestone M, Bouic PJD. A comparison of the survival benefit provided by putative immune modulators in the FIV (feline immunodeficiency virus) infected laboratory cat model. In: Proceedings of the 13th international AIDS conference; Durban. Bologna: Monduzzi Editore; 2000. p. 21-4.

25. Albrecht CF, Theron EJ, Kruger PB. Morphological characterisation of the cell-growth inhibitory activity of rooperol and pharmacokinetic aspects of hypoxoside as an oral prodrug for cancer therapy. S Afr Med J. 1995; 85:853-60.

26. Kruger PS, de V Albrecht CF, Uebenberg RW, Van Jaarsveld PP. Studies on hypoxoside and rooperol analogues from Hypoxis rooperi and H. latifolia and their biotransformation in man by using high-performance liquid chromatography with in-line sorption enrichment and diode array detection. J Chromatogr. 1994;662:71-8.

27. Nair VDP, Foster BC, Arnason JT, Mills EJ, Kanfer I. In vitro evaluation of human cytochrome P450 and P-glycoprotein-mediated metabolism of some phytochemicals in extracts and formulations of African potato. Phytomedicine. 2007;14(7):498-507.

28. Gwaza L, Wolfe AR, Benet LZ, Guglielmo BJ, Chagwedera TE, Maponga CC, Masimirembwa CM. In vitro inhibitory effects of Hypoxis obtusa and Dicoma anomala on cyp450 enzymes and p-glycoprotein. Afr J Pharm Pharmacol. 2009;3(11):539-46.

29. Musabayane CT, Xozwa K, Ojewole KA. Effects of Hypoxis hemerocallidea (Fisch. \& C.a. Mey.) [Hypoxidaceae] corm (African potato) aqueous extract on renal electrolyte and fluid handling in the rat. Ren Fail. 2005;27:763-70.

30. Ojewole JA. Anticonvulsant activity of Hypoxis hemerocallidea Fisch. \& C. A. Mey. (Hypoxidaceae) corm ('African potato') aqueous extract in mice. Phytother Res. 2008;22(1):91-6.

31. Nyinawumuntu A, Awe EO, Ojewole JA. Uterolytic effect of Hypoxis hemerocallidea Fisch. \& C.a. Mey. (Hypoxidaceae) corm ['African potato'] aqueous extract. J Smooth Muscle Res. 2008;44(5):167-76.

32. Erlwanger $\mathrm{KH}$, Cooper RG. The effects of orally administered crude alcohol and aqueous extracts of African potato (Hypoxis hemerocallidea) corm on the morphometry of viscera of suckling rats. Food Chem Toxicol. 2008;46(1):136-9.

33. Ojewole JA, Awe EO, Nyinawumuntu A. Antidiarrhoeal activity of Hypoxis hemerocallidea Fisch. \& C. A. Mey. (Hypoxidaceae) corm ('African potato') aqueous extract in rodents. Phytother Res. 2009;23(7):965-71. https://doi. org/10.1002/ptr.2732.

34. Liu Z, Wilson-Welder JH, Hostetter JM, Jergens AE, Wannemuehler MJ. Prophylactic treatment with Hypoxis hemerocallidea corm (African potato) methanolic extract ameliorates Brachyspira hyodysenteriae-induced murine typhlocolitis. Exp Biol Med (Maywood). 2010;235(2):222-30. https://doi.org/ 10.1258/ebm.2009.009269.

35. Chaturvedi P, Mwape MP. Effect of African potato (Hypoxis hemerocallidea) extract on oxidative stress induced by chloroquine in albino rats. Afr J Food Agric Nutr Dev. 2011;11(1):4476-89.

36. Oguntibeju OO, Meyer S, Aboua YG, Goboza M. Hypoxis hemerocallidea significantly reduced hyperglycaemia and hyperglycaemic-induced oxidative stress in the liver and kidney tissues of streptozotocin-induced diabetic male Wistar rats. Evid Based Complement Alternat Med. 2016;2016:1-10.

37. Nair VDP, Kanfer I. High-performance liquid chromatographic method for the quantitative determination of Hypoxoside in African potato (Hypoxis hemerocallidea) and in commercial products containing the plant material and/or its extracts. J Agric Food Chem. 2006;54:2816-21.

38. Ncube B, Ndhlala AR, Okem A, Van Staden J. Hypoxis (Hypoxidaceae) in African traditional medicine. J Ethnopharmacol. 2013;150(3):818-27. https:// doi.org/10.1016/j.jep.2013.10.032

39. Bouic PJD. The role of phytosterols and phytosterolins in immune modulation: a review of the past 10 years. Curr Opin Clin Nutr Metab Care. 2001:4:471-5

40. Ling WH, Jones PJH. Dietary phytosterols: a review of metabolism, benefits and side effects. Life Sci. 1995;57:195-206.

41. Saeidnia S, Manayi A, Gohari AR, Abdollahi M. The story of beta-sitosterol-a review. Eur J Med Plants. 2014;4(5):590.

42. Inkomfe Capsules (African Potato). Natures Health. http://www. natureshealth.co.za/product/inkomfe_capsules/36. Accessed 17 Oct 2018. 
43. African Potato Capsule. Green Herbs \& Nutrition's Stores. https:// herbsandnutritionstores.com/african-potato. Accessed 17 Oct 2018.

44. Colour in the cold. Puer Orijins Catalogue and specials. http://www. botlebuhle.co.za/c/rsapuerfull.pdf. Accessed 17 Oct 2018.

45. Wen H, Jung H, Li X. Drug delivery approaches in addressing clinical pharmacology-related issues: opportunities and challenges. AAPS J. 2015; 17(6):1327-40. https://doi.org/10.1208/s12248-015-9814-9.

46. Grinsztejn B, Hosseinipour MC, Ribaudo HJ, Swindells S, Eron J, Chen YQ HPTN 052-ACTG Study Team. Effects of early versus delayed initiation of antiretroviral treatment on clinical outcomes of HIV-1 infection: results from the phase 3 HPTN 052 randomised controlled trial. Lancet Infect Dis. 2014; 14(4):281-90 https://doi.org/10.1016/S1473-3099(13)70692-3.

47. Usman $\mathrm{H}$, Haruna AK, Akpulu IN, llyas M, Ahmadu AA, Musa YM. Phytochemical and antimicrobial screenings of the leaf extracts of Celtis integrifolia. Lam J Trop Biosci. 2005:5(2):72-6.

48. Sermakkani M, Thangapandian V. Phytochemical Screening for Active Compounds in Pedalium murex L. Recent Res Sci Technol. 2010;2(1):110-14.

49. Ali N, Shah SW, Shah I, Ahmed G, Ghias M, Khan I. Cytotoxic and anthelmintic potential of crude saponins isolated from Achillea Wilhelmsii C. Koch and Teucrium Stocksianum boiss. BMC Complement Altern Med. 2011; 11:106. https://doi.org/10.1186/1472-6882-11-106.

50. Schneider $\mathrm{G}$, Wolfling J. Synthetic cardenolides and related compounds. Curr Org Chem. 2004;8:1381-403.

51. Serrano J, Puupponen-Pimiä R, Dauer A, Aura AM, Saura-Calixto F. Tannins: current knowledge of food sources, intake, bioavailability and biological effects. Mol Nutr Food Res. 2009:53(S2):S310-29.

52. Morkunas I, Ratajczak L. The role of sugar signaling in plant defense responses against fungal pathogens. Acta Physiol Plant. 2014;36(7):1607-19.

53. Pallarès $\mathrm{V}$, Calay $\mathrm{D}$, Cedó $\mathrm{L}$, Castell-Auví $\mathrm{A}$, Raes M, Pinent $\mathrm{M}$, Ardévol A, Arola L, Blay M. Additive, antagonistic, and synergistic effects of procyanidins and polyunsaturated fatty acids over inflammation in RAW 264.7 macrophages activated by lipopolysaccharide. Nutrition. 2012;28(4): 447-57.

54. Ward BA, Gorski JC, Jones DR, Hall SD, Flockhart DA, Desta Z. The cytochrome P450 2B6 (CYP2B6) is the main catalyst of efavirenz primary and secondary metabolism: implication for HIV/AIDS therapy and utility of efavirenz as a substrate marker of CYP2B6 catalytic activity. J Pharmacol Exp Ther. 2003;306:287-300.

55. Monera-Penduka TG, Nhachi C, Maponga C, Morse G. A Research Strategy for the Development of Clinical Evidence for Traditional Herbal Medicine. http://www.iamp-online.org/sites/iamp-online.org/files/06.\%20A\%2 OResearch\%20Strategy\%20for\%20the\%20Development\%20of\%20Clinical.pdf. Accessed 17 Oct 2018

\section{Publisher's Note}

Springer Nature remains neutral with regard to jurisdictional claims in published maps and institutional affiliations.

Ready to submit your research? Choose BMC and benefit from:

- fast, convenient online submission

- thorough peer review by experienced researchers in your field

- rapid publication on acceptance

- support for research data, including large and complex data types

- gold Open Access which fosters wider collaboration and increased citations

- maximum visibility for your research: over $100 \mathrm{M}$ website views per year

At $\mathrm{BMC}$, research is always in progress.

Learn more biomedcentral.com/submissions 